\title{
Impression Management Tactics as a psychological booster for the communication of IT employees - SMART PLS Approach
}

\author{
C. Vijayabanu ${ }^{1}$, C. Therasa $^{2}$, S. Anjali Daisy ${ }^{3}$ \\ SASTRA Deemed To Be University, India
}

\begin{abstract}
Impression management (IM) is a technique or tactic followed by employees to form favorable perceptions. The current study analyzed the relationship of various facets (Deception, Defensive, Exemplification, Ingratiation, Model behavior, and Self-promotion) of impression management and its effect on global assignment, work-life balance, and career growth. Furthermore, the current study also analyzed the impact of IM on the psychological behavior of IT employees and conceptualized a model using SmartPLS (Partial Least Squares) approach. Questionnaires were distributed to 225 employees (36\% female) in a Private Software Company in Chennai, India. Results indicate that the IM facets contribute $51.2 \%$ in predicting the individual psychological factor composed of global assignment, work-life balance, and career growth.
\end{abstract}

Keywords: Impression management, global assignments, career growth, work-life balance, Smart PLS

Las tácticas de gestión de impresión como mejora psicológica para la comunicación del personal de TI: Un enfoque SMART PLS

El manejo de la impresión (IM) es una técnica o táctica seguida por los empleados para formar percepciones favorables. El estudio actual analizó la relación de varias facetas (decepción, defensa, ejemplificación, congraciarse, comportamiento modelo y autopromoción) de la gestión de impresiones y su efecto en las tareas globales, el equilibrio entre la vida laboral y profesional y el crecimiento profesional. Además, el estudio actual también analiza el impacto de la IM en el comportamiento psicológico de los empleados de TI y conceptualiza un modelo utilizando el enfoque de SmartPLS (mínimos cuadrados parciales). Se distribuyeron cuestionarios a 225 empleados (36\% mujeres) en una empresa de software privada en Chennai, India. Se encontró que las facetas de IM contribuyen al $51.2 \%$ en la predicción del factor psicológico individual compuesto por las tareas globales, el equilibrio entre la vida laboral y profesional y el crecimiento profesional.

1 PhD in Commerce-Human Resource Management. Associate Professor, School of Management, SASTRA Deemed to be University. Postal Address: Thirumalaisamudram, Thanjavur, Tamil Nadu 613401, India. Contact: vijayabanu@mba.sastra.edu, https://orcid. org/0000-0002-0125-4534

2 MBA. Assistant Professor, School of Management, SASTRA Deemed to be University. Postal Adress: Trichy-Tanjore Road, Thirumalaisamudram, Thanjavur, Tamil Nadu 613401, India. Contact: therasa@mba.sastra.edu, https://orcid.org/0000-0001-7052-9805

3 Research Scholar, School of Management, SASTRA Deemed to be University. Postal Address: Thirumalaisamudram, Thanjavur, Tamil Nadu 613401, India. Contact: anjalidaisy2011@ gmail.com, https://orcid.org/0000-0003-1207-5002?lang=en 
Palabras clave: manejo de impresión, tareas globales, crecimiento profesional, equilibrio vida-trabajo, Smart PLS

Táticas de gerenciamento de impressóes como um reforço psicológico para a comunicaçáo de funcionários de TI - Abordagem SMART PLS

A gestão da impressão é uma técnica ou tática seguida pelos funcionários para formar percepçóes favoráveis. O presente estudo analisou a relaçáo de várias facetas (Decepção, Defesa, Exemplificação, Congraçar-se, Comportamento Modelo e Autopromoção) da gestão das impressóes e seu efeito nas tarefas globais, no equilíbrio entre trabalho e vida pessoal, e no crescimento profissional. Além disso, o presente estudo analisou o impacto da gestão da impressão no comportamento psicológico dos funcionários de TI e conceituou um modelo usando a abordagem SmartPLS (Partial Least Squares). Os questionários foram distribuídos para 225 funcionários (36\% mulheres) em uma empresa de software privado em Chennai, na Índia. Descobriu-se que as facetas gestão da impressão contribuem com 51,2\% na previsão do fator psicológico individual que compreende tarefas globais, o equilíbrio entre trabalho e vida pessoal, e o crescimento profissional.

Palavras-chave: gestão de impressôes, tarefas globais, crescimento profissional, equilíbrio trabalho-vida, Smart PLS

La tactique de gestion des impressions comme moteur psychologique pour la communication des employés IT: une approche SMART PLS.

La gestion des impressions (IM) est une technique ou une tactique suivie par les employés pour former des perceptions favorables. La présente étude a analysé la relation entre diverses facettes (tromperie, défense, exemplification, ingratiation, comportement modèle et autopromotion) de la gestion des impressions et ses effets sur la cession globale, la conciliation travail-famille et la croissance de carrière. En outre, la présente étude analyse également l'impact de la messagerie instantanée sur le comportement psychologique des employés informatiques et conceptualise un modèle utilisant l'approche SmartPLS (Partial Least Squares). Des questionnaires ont été distribués à 225 employés (dont 36\% de femmes) dans une entreprise privée de logiciels à Chennai, en Inde. On constate que les facettes de la GI contribuent à $51.2 \%$ dans la prédiction du facteur psychologique individuel.

Mots clés: gestion des impressions, missions globales, évolution de carrière, équilibre travailvie personnelle, SMART PLS. 
Impression Management (IM) or Self -Presentation is a practice or a method by which all individuals attempted to manage or strive to control the impressions. The impressions are given preferences or due weight through the preference, feelings or judgments to others' thoughts and opinions about them (Bolino, Wiltshire \& Lee, 2016). The individuals are pleased to show their positive image to others to have a good feeling about them (Nasr Esfahani, 2002; Giacalone \& Rosenfeld, 2013). Nowadays, individuals, tend to use some impression techniques to impress others to get any long-term benefits (Schlenkar, 1980; Brouer et al., 2016; Peck \& Hogue, 2018). The organizational impression management techniques are followed by the employees to influence the employer's behaviour, attitudes, and belief (Yu, 2019)

Goffman (1959) developed the term 'impression management' and defined it as a purposeful action that people follow to build optimistic and positive distinctiveness and social image (Zerbe \& Paulhus, 1987). The facets of impression management have a real influence on various constructs such as career success (Judge \& Bretz, 1994) and supervisor's evaluation (Ferris et al., 1994; Bourdage et al., 2015). It has recently earned much interest because people working in organizations are in teams, and they are working cross-functionally. While working in groups, individuals often use some impression management tactics to justify their intelligence level and their organization citizenship behaviour (OCB). Extensive research has confirmed that individuals shape their communal images based on the perceived values and choices of others (Montagliani \& Giacalone, 1998; Goveetal, 1980; Giacalone \& Rosenfeld, 2013; Bolino et al., 2016; Kacmer et al 2016; Brouer et al. 2016; Peck \& Hogue, 2018; Brouer et al., 2016). In this manner, impression management is the method by which the individual manage the impressions of other individuals, and this process plays an critical role in determining the interpersonal behaviour (Leary \& Kowalski, 1990). 
Research on impression management aimed to comprehend the tactics employees use to form those perceptions (DuBrin, 2011). All employees are conscious of their impact based on the managers' discernment, which has a greater effect on career growth, job assignments, rewards, and promotions (Feldman \& Klich, 1991; Bourdage et al., 2015; Peck \& Hogue, 2018). IM has been flourishing as a new area of research, as it analyses the influence of the superior's perception of subordinates' performance. It is the individual psychological factors which act as a basis perception formation about people (Kacmer et al., 2016; Spence \& Keeping, 2011). Then, IM can be viewed as a technique which can be used by both the individual and the organization, where it can be exercised either positively or deceptively which might influence or affected the work life, career growth and global assignments (Tsai et al., 2010; Erdogan, 2011; Wayne \& Ferris, 1990; Drory \& Zaidman, 2007; Montagliani \& Giacalone, 1998).

IM has fascinated and gained concentration as a primary interpersonal practice in the organization (Baumeister, 1986; Schlenker, 1985; Hogan, 1982). There exists some literature which relates impression management with Organizational Citizenship behaviour (Bolino, 1999; Yu, 2019). It also has a significant sway on the performance appraisal activities like promotions, transfers, hiring decisions and career growth (Bolino et al., 2008; Bourdage et al., 2015). Every individual has their own characteristics, and everyone likes to act smart in this competitive business world. It is the human tendency to show only the positive side to others, and they often use impression management to sustain and to elevate to a higher level in their jobs. Research studies, which focus on the factors determining employees' performance ratings, found the role of impression management. There are also studies that assess subordinate's impression management tactics to influence their supervisors while doing performance appraisals (Vijayabanu \& Therasa, 2016).

In IT organizations, employees' performance has been measured using performance management system, wherein team and project heads are the decision makers who record the self-appraisal forms, and 
then the appraiser provides final grades or ratings for measuring the performance in quantitative form. During this process, impression management plays a significant role in the appraiser's decision-making process (Rosenfeld et al., 2015; Spence \& Keeping, 2011).

Hence, the present study depicted on the factors influencing impression management techniques on three behavioural variables, namely global assignment, work-life balance, and career growth by formulating a suitable hypothesis. The key issues and questions in the current study are whether employee impression management intention will influence the workplace relationships in determining global assignments, issues about work-life balance, and career prospects (Belsechak et al., 2010). According to impression management theory, employees assume that superiors' opinion positively relates to their workplace issues and relationships and they started "backing up behaviour" (Porter et al., 2003; Therasa \& Vijayabanu, 2015). The conceptual model based on IM (Jones \& Pittman, 1982) and behavioural outcome of the individuals through the tactics of Work life balance, Career growth and Global assignments (Tsai et al. 2010; Erdogan, 2011; Wayne \& Ferris, 1990; Drory \& Zaidman, 2007) is shown in Figure 1.

\section{Impression Management}

It is a demeanor to keep some sought of pictures of oneself (Gardner \& Martinko, 1988). IM is the strategy by which individuals endeavor to understand the picture of others towards them (Rosenfeld et al., 2002). In recent years, specialists have given colossal consideration regarding understanding impression administration in associations. Impression Management ended with more intentional and focused activities by the people, based on the assumption that they will have an incremental advantage due to distinct impressions (Schlenker \& Weigold, 1992). The fundamental aim of individuals is to be seen by others emphatically and refrain them from being seen unfavourably (Rosenfeld, 1997). Impression Management (IM) is characterized as purposeful or unconscious effort to organize the perceptions that are expected in social coordinated efforts (Schlenker, 1980; Rosenfeld, 
Giacalone, \& Riordan, 1995). Impression Management dependably has some sentiments about other people that result in promoting and discovering imaginative routes in and around the association. (Provis, 2010). People worry about the perception of others also because it will have impacts that are more significant intentionally and unintentionally (Schlenker, 1980).

\section{Impression Management and behavioural outcomes}

People who follow impression management dependably have high grounds and take the upper hand over others (Gardner \& Martinko, 1988; Sharp \& Getz, 1996; Wayne \& Liden, 1995). As indicated by Taylor (1997), impression creation is an essential general pattern for all people and dealing with these impressions influences one's living profoundly. There is a necessity for those of various leveled settings to grasp the central segments or creates required in impression administration (Crane \& Crane, 2004). Impression management frameworks have a significant measure to do attitudinal training, personality, career aspiration and lifestyle management (Jones \& Pittman, 1982; Therasa, \& Vijayabanu, 2015; Therasa \& Vijayabanu, 2016). Savvy effects of impression organization and various leveled issues on word related and hierarchical measurements affect the execution (Zivnuska \& Kacmar, 2004). Impression management is a conscious or subconscious process by which people attempted to influence the perspective of other people (i.e.) about a man, event or occasion. It is composed of five dimensions: Self-promotion, exemplification, ingratiation, defensive and deception.

\section{Self-Promotion}

Self- Promotion is an activity done forcefully to create a positive impression in the minds of others through some unusual words, qualities, and higher level and so forth (McFarland et al., 2005). It includes the process of elucidations by which the individual clarifies on the various reasons behind unenthusiastic results (Shaw et al., 2003; Tsai et al., 2010). Self-advancement is frequently utilized as a tool of impres- 
sion management when the positive likelihood of their cases is low or criticized poorly (Rosenfeld et al., 1995). In a hierarchical setting, the impression technique is used to withhold the positions, adhere with practices and to elevate to higher levels (Rosenfeld et al., 1995).

\section{Exemplification}

People will endure helping other people yet in all actual endeavors to make others feel regretful because they are not acting in the same ethical way. The objective can lessen their sentiments of blame by at any rate supporting the reason for the exemplified (Jones \& Pittman, 1982). This strategy can include critical generosity (Rosenfeld et al., 1995). Employees utilizing the strategy of supplication are seen as apathetic, and when they request with this approach, there lies the risk of abuse (Rosenfeld et al.,1995). This strategy underlines the worker's reliance and shortcoming in acquiring assistance from an all in a more efficient way than others. (Rosenfeld et al., 1995)

\section{Ingratiation}

It helps to get possibilities of reinforcing the relationship amongst the people who are extraverted and present positive interpersonal citizenship (Chiaburu \& Stoverink, 2006). It supports subjective, motivated, and passionate methodology towards impression administration and helps to gather the spectator responses (Gardner \& Martinko, 2011).

\section{Defensive}

Impression management is an important instrument accessible to brief about their specialist's skills and secures their work showcase position in the first instance, and in a later stage to supports professional success. The relationship between upward impression management and career commitment depend on subordinates' impression management conduct. IM helps to create impacts, and it executes the positive evaluations and comparisons of subordinates by the managers' preferences (Wayne \& Liden, 2011). 


\section{Deception}

Stevens and Kristoff (1995) observed the degree of self-advancement and feelings of congruity utilized by employees amid real meetings and analysed the effect of such strategies on meeting results. Impression Management hypothesis, ideas, and intuitions help to comprehend better for the hierarchical growth (Bolino, Kacmar, Turnley \& Gilstrap, 2008). Organizations utilize IM strategies that will be more emphatically help to plan and organise the impressions that partners hold (Sandberg \& Holmlund, 2015). IM also identify the management strategies and methods that recognize the role and processes need to be played in the organizational life (Seth Accra Jaja, 2003). Managers ought to be careful in considering the underlying impact that IM has on their role to impartially assess new subordinate (Mark, Bolino, Klotz \& Daniels, 2014).

The Behavioural outcome of the impression management tactics studied are (a) Work life balance, (b) Career growth and (c) Global assignments. Out of the three outcome Global assignments had the higher loadings in a previous study (Montagliani \& Giacalone, 1998).

Given this, the objective of the present study is to assess the relationship of various dimensions of impression management (Deception, Defensive, Exemplification, Ingratiation, Model behaviour and Self-promotion) and individual behaviour such as global assignment, work-life balance, and career growth (Figure 1).

\section{Method}

\section{Participants}

The questionnaires were distributed to 225 employees $(36 \%$ female) in a private software company in Chennai, India. $49 \%$ of the employees belong to the age group of 25-35 years, while $25 \%$ of the employees were above 45 years. $58 \%$ of the employees were undergraduates, and $42 \%$ of the employees were postgraduates. $49 \%$ of employees have 3-5 years of experience, while $15 \%$ of employees had 
10-15 years of experience. The questionnaire was distributed and the purpose was clearly stated. The researcher assured the responses given would not be individually discussed in any place (See Table 1).

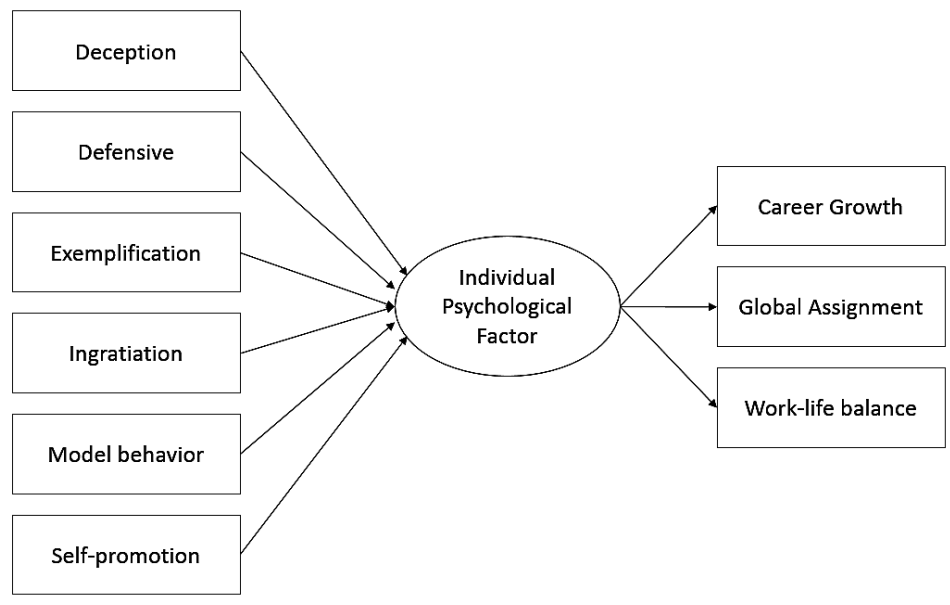

Figure 1. Conceptual Research Framework

\section{Table 1}

Demographic Details of employees

\begin{tabular}{llcc}
\hline Variables & Category & Frequency & $(\%)$ \\
\hline \multirow{2}{*}{ Age } & Between 25-35 years & 110 & 49 \\
& Between 36-45 years & 60 & 26 \\
& 46 and above & 55 & 25 \\
\hline \multirow{2}{*}{ Gender } & Male & 143 & 64 \\
& Female & 82 & 36 \\
\hline \multirow{2}{*}{ Qualification } & Under Graduate & 130 & 58 \\
& Post Graduate & 95 & 42 \\
\hline \multirow{2}{*}{ Experience } & Between 3-5 years & 110 & 49 \\
& Between 5 -10 years & 82 & 36 \\
& Between 10-15 years & 33 & 15 \\
\hline
\end{tabular}




\section{Measures}

Impression Management was assessed with a scale developed by Jones and Pittman (1982), with twenty-eight statements. The framework proposed by Jones \& Pittman was tested by Bolino and Turnley (1999) by conducting five studies using a variety of samples. Different validities (content, convergent and discriminant validities) were checked and the taxonomy was confirmed (Bolino \& Turnley, 1999). Further, Kacmar, Harris and Nagy (2007) validated the Impression Management Scale by assessing convergent and discriminant validity by using three samples of full-time employees. The scale used has an extensive categorization to capture the impact of impression management behaviours, which includes the following dimensions: Deception, Defensive, Exemplification, Ingratiation, Model behaviour and Self-promotion. The factors are defensive strategies with four statements and individual behavioural outcome with three due to Impression Management strategies-Worklife Balance, Carrer Growth \& Global Assignments (Tsai et al., 2010, Erdogan, 2011; Wayne \& Ferris, 1990; Drory \& Zaidman, 2007).

\section{Table 2}

Apparent elements determining the facets of impression management and the individual behaviour based on the literature

\begin{tabular}{llll}
\hline No & Factors & Author & $\alpha$ \\
\hline 1 & $\begin{array}{l}\text { Impression management Scale (Deception, } \\
\text { Defensive, Exemplification, Ingratiation, } \\
\text { Model behaviour and Self-promotion) }\end{array}$ & $\begin{array}{l}\text { Jones and Pittman } \\
(1982)\end{array}$ & .78 \\
2 & $\begin{array}{l}\text { Individual Psychological Factor: Worklife } \\
\text { Balance, Carrer Growth \& Global } \\
\text { Assignments }\end{array}$ & Tsai et al. (2010) & .78 \\
& & Erdogan (2011) & \\
& & Wayne \& Ferris(1990) & \\
& & & \\
\end{tabular}

\section{Procedure}

The current study is based on the primary data collected through the questionnaires on a private software company in Chennai. 250 
questionnaires were distributed to employees of which 237 were collected from the employees with the $94.8 \%$ response rate. Out of which 9 questionnaires (3.6\% of the dispersed questionnaires) had incomplete data. Out of the 258 entirely filled questionnaires, 255 questionnaires were taken for analysis. The recommended threshold on the number of question was one hundred fifteen (Bartlett et al., 2001).

\section{Data Analysis}

The current study analyses the effects of Impression management using SMART PLS (Partial Least Squares) approach (Liu, Bingsheng, et al., 2017). The PLS -SEM model is a multivariate tool that combines linear regression and factor reduction method to estimate a set of interrelated dependent relationships concurrently. The PLS -SEM model was considered as a superior method to multiple regression methods because it considers multi-collinearity (Falk and Miller, 1992) based on dependent and independent factors. The bootstrapping method was adopted in the current study to decide on the significant implications of factor loadings, path coefficients and variances

\section{Results}

The factors Self-promotion $(M=3.44)$, Ingratiation $(M=3.39)$, Exemplification $(M=3.72)$, Defensive $(M=3.62)$, Deception $(M=3.81)$ and model behaviour $(M=3.54)$ have been taken, and the average scores have been calculated. Among the average scores for the factors creating impressions in the workplace, the factor Deception $(M=3.81)$ has been ranked one, Exemplification $(M=3.72)$ has been ranked as second, Defensive $(M=3.62)$ as third. The overall Cronbach Alpha Coefficient for the factors is .783 confirming the internal consistency between the factors. It is concluded that reliability coefficient of 0.7 or higher is considered as 'acceptable' in most of the social science research. The Kaiser-Meyer-Olkin measure of sampling adequacy (.698) verified the appropriateness of the sample. 


\section{Table 3}

Descriptive analysis of factors determining workplace impressions for employees

\begin{tabular}{lcccc}
\hline Factors & $M$ & $S D$ & Chi-Square & $p$ \\
\hline Self-Promotion & 3.44 & 1.23 & 210.37 & 0.00 \\
Ingratiation & 3.39 & 1.19 & 126.81 & 0.00 \\
Exemplification & 3.72 & 1.21 & 188.78 & 0.00 \\
Deception & 3.81 & 1.01 & 62.62 & 0.00 \\
Defensive & 3.62 & 1.21 & 18.78 & 0.00 \\
Model Behaviour & 3.54 & 1.15 & 11.67 & 0.00 \\
\hline
\end{tabular}

Cronbach Alpha:.78

KMO measure of sampling adequacy: .70

\section{Assessment of the Measurement Model}

All the items determining the level of creating impression towards people in the organization have factor loading higher than .50 (Nunnally \& Bernstein, 1994) which concludes that the convergent validity is right among the research constructs in the current study. It is also concluded that the higher item loadings towards the research construct determine the upper-level association and the lower loadings as the independent association among construct. Barclay et al., (1995) concludes that loading of .70 or higher is right to prove for convergent validity. So the six dimensions of impression management (Deception, Defensive, Exemplification, Ingratiation, Model and Self Promotion) reflecting impact towards the behaviour of the individual in creating evidence of impressions and personal branding are confirmed by the constructs. People utilize unique methods for boosting their picture which fall into two classes exertion increment they engage others (self-enhancement). Furthermore, endeavors to make the objective individual feel high in different ways (other enhancement). Self-upgrade make utilization of particular procedures to twist reality and improve one's allure while in other-improvement strategies utilized have a crucial part as an impact of producing preferring for the individual in charge of them (Byrne, 1992). 


\section{Table 4}

Accuracy Analysis of Statistics

\begin{tabular}{|c|c|c|c|c|c|c|}
\hline $\begin{array}{l}\text { Construct } \\
\text { category }\end{array}$ & $\begin{array}{l}\text { Research } \\
\text { construct }\end{array}$ & $\begin{array}{l}\text { Factor } \\
\text { Loading }\end{array}$ & $\begin{array}{l}\text { LV Index } \\
\text { Value }\end{array}$ & $\begin{array}{c}\text { Cronbach's } \\
\text { value }\end{array}$ & $\begin{array}{l}\text { Composite } \\
\text { Reliability }\end{array}$ & $\begin{array}{l}\text { AVE } \\
\text { Value }\end{array}$ \\
\hline \multirow{4}{*}{ Deception } & DECEP1 & .7733 & \multirow{4}{*}{3.8227} & \multirow{4}{*}{.7291} & \multirow{4}{*}{.7284} & \multirow{4}{*}{.5069} \\
\hline & DECEP2 & .5176 & & & & \\
\hline & DECEP3 & .6558 & & & & \\
\hline & DECEP4 & .5759 & & & & \\
\hline \multirow{3}{*}{ Defensive } & DEFEN1 & .7733 & \multirow{3}{*}{3.8272} & \multirow{3}{*}{.7491} & \multirow{3}{*}{.7896} & \multirow{3}{*}{.5592} \\
\hline & DEFEN2 & .5176 & & & & \\
\hline & DEFEN3 & .6558 & & & & \\
\hline \multirow{5}{*}{ Exemplification } & EXE3 & .6467 & \multirow{5}{*}{3.9661} & \multirow{5}{*}{.7191} & \multirow{5}{*}{.7626} & \multirow{5}{*}{.5029} \\
\hline & EXE4 & .4784 & & & & \\
\hline & EXE5 & .5671 & & & & \\
\hline & EXE6 & .7602 & & & & \\
\hline & EXE7 & .7442 & & & & \\
\hline \multirow{6}{*}{ Ingratiation } & ING1 & .5782 & \multirow{6}{*}{3.373} & \multirow{6}{*}{.7091} & \multirow{6}{*}{.7008} & \multirow{6}{*}{.5867} \\
\hline & ING2 & .5842 & & & & \\
\hline & ING4 & .4465 & & & & \\
\hline & ING5 & .4145 & & & & \\
\hline & ING6 & .6726 & & & & \\
\hline & ING7 & .4703 & & & & \\
\hline \multirow{4}{*}{ Model Behaviour } & MB 1 & .6121 & \multirow{4}{*}{3.5609} & \multirow{4}{*}{.7791} & \multirow{4}{*}{.8589} & \multirow{4}{*}{.6075} \\
\hline & MB 2 & .8568 & & & & \\
\hline & MB 3 & .8653 & & & & \\
\hline & $\mathrm{MB} 4$ & .7567 & & & & \\
\hline \multirow{7}{*}{ Self Promotion } & SP10 & .5015 & \multirow{7}{*}{3.4419} & \multirow{7}{*}{.7591} & \multirow{7}{*}{.7805} & \\
\hline & SP2 & .5838 & & & & \\
\hline & SP3 & .5304 & & & & \\
\hline & SP4 & .4501 & & & & .5422 \\
\hline & SP6 & .6723 & & & & \\
\hline & SP8 & .7299 & & & & \\
\hline & SP9 & .578 & & & & \\
\hline & $\mathrm{BO} 1$ & .1049 & & & & \\
\hline $\begin{array}{l}\text { Denaviour } \\
\text { Outcome }\end{array}$ & $\mathrm{BO} 2$ & .1637 & & & & \\
\hline & $\mathrm{BO} 3$ & .4925 & 5.5778 & .7431 & .5162 & .5332 \\
\hline
\end{tabular}

Nota: Impression management facets vs. Behavioural outcome: $R^{2}=51.2$ 
The Cronbach alpha, Composite Reliability and AVE Value are higher than the minimum accepted level (Fornell, C., \& Larcker, 1981) in the current study. Always .70 or higher is preferable and, for an exploratory study, .40 or higher is acceptable (Hulland, 1999). The result shows that there is no ruthless predicament of multicollinearity between the independent variables and also make sure about the discriminant validity too. The results confirm that the study has reliability and validity. The inter construct correlation matrix was formulated for the six dimensions of factors creating the impression and personal branding and it is shown in table 5 .

\section{Table 5}

Inter construct correlation Matrix

\begin{tabular}{lccccccc}
\hline Factors & 1 & 2 & 3 & 4 & 5 & 6 & 7 \\
\hline Behavioural Outcome &. $\mathbf{7 3}^{*}$ & & & & & & \\
Deception & .23 & $.7 \mathbf{1}^{*}$ & & & & & \\
Defensive & .35 & .42 &. $\mathbf{. 4}^{*}$ & & & & \\
Exemplification & .28 & .42 & .49 & $.70^{*}$ & & & \\
Ingratiation & .29 & .16 & .39 & .39 & $.76^{*}$ & & \\
Model behaviour & .64 & .12 & .13 & .10 & .19 & $.77^{*}$ & \\
Self-promotion & .31 & .06 & .24 & .28 & .60 & .16 & $.73^{*}$ \\
\hline
\end{tabular}

Note: ${ }^{*}$ Discriminant Validity

As shown in Table 5 all the variables have acceptable discriminant validity, as the diagonal numbers (shown with *) which are the square root of AVE are superior than off-diagonal correlation value in the corresponding rows and columns (Chin, 1998). The table studied the level of correlation between factors creating impressions and personal branding and the impact generated by the behaviour of employees in the organization. It also concludes that there is a noteworthy constructive positive association between the six dimensions of supervisory competencies. The AVE test values and the relationship has been measured by the measurement model. The discriminant validity test 
approves the square root of the relevant AVE of each variable should exceed the correlation between the factor. The goal of PLS path modeling is principal to estimate the variances of endogenous constructs and in turn with their relevant manifest variables (Chin 1998). The Smart PLS model (Figure 1) is authenticated by Endogenous LV and Goodness of fit (GoF) (Panagiotis Trivellas et al. 2013). The proposed goodness of fit is .5013 which surpass the suggested threshold values of GoF>.36 suggested by Wetzels, Odekerken-Schröder \& Van Open (2009) and Henseler and Sarstedt (2012). Thus, this study confirmed and concluded that the research model developed by the researcher has an on the whole or overall goodness of fit.

\section{Assessment of the Structural Model}

The $R$ square value of $(R=.512)$ for factors impacting behavioural outcome due to the factors of impression management. The path relationship between factors of impression management and the behavioural outcome is estimated using the standardized regression coefficient. The bootstrap method was used to calculate the $\mathrm{t}$ statistic to assess the significance of the model Chin, W.W. (1998). Drory \& Zaidman (2007) suggested that IM behaviours have been studied in the organizational context about many areas such as interviews, performance appraisal, and career success. The factors of impression management parameter and the behavioural outcome are created as the hypothesized relationship is shown in Figure 2.

\section{Explanation of target endogenous variable variance}

The $R$ square value of the dependent factor viz. factors of impression management impacted the individual behavioural outcome of employees (.512). The results validated the effect, and the inner model suggests the possible relationship between, Model behaviour developed by the individual and the behavioural outcome is $58.0 \%$. Self-promotion strategies developed by the individual and the resultant behavioural outcome are $18.1 \%$. Defensive strategies developed by the individual and the behavioural outcome are 19.8\%. Exemplification strategies developed by individual employees will impact the behavioural outcome by $7.1 \%$. 


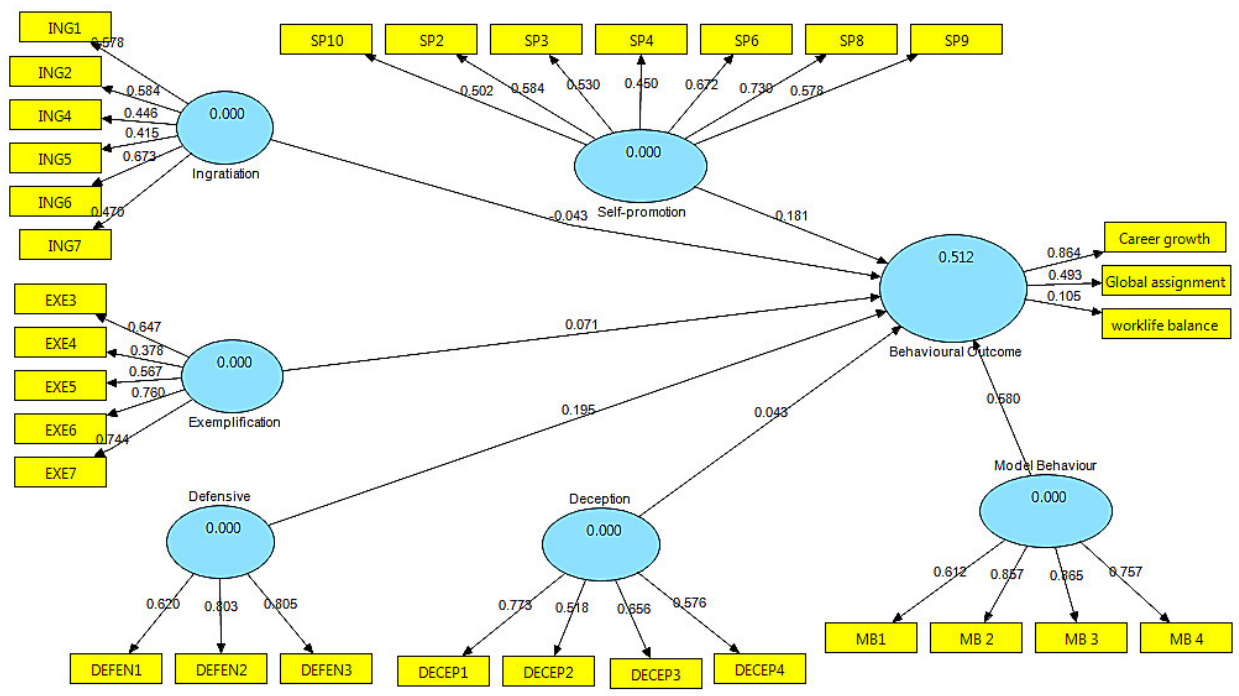

Figure 2. Measurement and Structural Model Results

\section{Explanation of target endogenous variable variance}

The $R$ square value of the dependent factor viz. factors of impression management impacted the individual behavioural outcome of employees (.512). The results validated the effect, and the inner model suggests the possible relationship between, Model behaviour developed by the individual and the behavioural outcome is $58.0 \%$. Self-promotion strategies developed by the individual and the resultant behavioural outcome are $18.1 \%$. Defensive strategies developed by the individual and the behavioural outcome are 19.8\%. Exemplification strategies developed by individual employees will impact the behavioural outcome by $7.1 \%$.

For the structural model, the path model developed has been considered as regression coefficients which are inferred with $t$ statistics. It is a nonparametric technique calculated using the bootstrap method in determining the precision of PLS results, (Chin, 1998). The model fit was assessed by the $R$ square values based on the assumed hypoth- 
esis. The $R$ square value determines the quantum of variance for the endogenous variables which are determined by the antecedents and the results are shown in table 5 (Chin, 1998).

\section{Table 6}

Results of Structural Equation Model Analysis

\begin{tabular}{lcccl}
\hline Particulars & Hypothesis & $\begin{array}{c}\text { Path } \\
\text { Coefficient }\end{array}$ & $t$ & Decision \\
\hline $\begin{array}{l}\text { Deception - } \\
\text { Behavioural Outcome }\end{array}$ & $\mathrm{H} 1$ & .0431 & .5061 & Not Supported \\
$\begin{array}{l}\text { Defensive - } \\
\text { Behavioural Outcome }\end{array}$ & $\mathrm{H} 2$ & .1955 & 1.6741 & $\begin{array}{l}\text { Supported } \\
(10 \%)\end{array}$ \\
$\begin{array}{l}\text { Exemplification - } \\
\text { Behavioural Outcome }\end{array}$ & $\mathrm{H} 3$ & .0706 & .7122 & Not Supported \\
$\begin{array}{l}\text { Ingratiation - } \\
\text { Behavioural Outcome }\end{array}$ & $\mathrm{H} 4$ & .0433 & .3536 & Not Supported \\
$\begin{array}{l}\text { Model behaviour - } \\
\text { Behavioural Outcome }\end{array}$ & $\mathrm{H} 5$ & .5802 & 3.0101 & $\begin{array}{l}\text { Supported } \\
\text { Self-promotion - }\end{array}$ \\
$\begin{array}{l}\text { Sehavioural Outcome } \\
\text { Beharion }\end{array}$ & $\mathrm{H} 6$ & & & $\begin{array}{l}\text { Supported } \\
(1 \%)\end{array}$ \\
\hline
\end{tabular}

Note: $T$ Statistic $>1.96$ for $5 \% ; p<.005$

The $R$ square value of the dependent value specifies that the model was able to relate to the behavioural outcome of the individual employee is .52. The bootstrap method of Smart PLS has been used to measure the level of $s$ consequence or statistical significance of the path coefficients. It is comparable to the beta values of regression analysis. The degree of defensive strategies of the individual that create impact towards the employees is positively associated $(\beta=.1955, p<.010)$. Individuals use various IM strategies in the organization to build the relationship and to have the positive behavioural outcome (Kenneth, Michele, Suzanne \& Jason, 2007). 
Similarly, the model behaviour developed by the individual and self-promotion strategies of the individual within the organization will create impact in the behaviour positively $(\beta=.58, p<.001 ; \beta=$ $.181, p<.001)$ respectively. People who perform impression administration efficiently do regularly increase essential favourable circumstances by and large (Sharp and Getz, 1996; Wayne and Liden, 1995). Overall, all the structural relationships portrayed in the research model in the figure 2 are significant.

\section{Discussion}

The current study identified the factors determining IM with the sample of IT employees and also analyzed the behavioural impact that is intended outcome or predetermined outcome based on IM techniques in the organization. IT sector has been chosen for the survey because the industry leads the employees with a lot of impressions and competitions across the globe. The current study has taken the variables Deception, Defensive, Exemplification, Ingratiation, Model, Self-promotion and the results were analysed using smart PLS modelling technique. It is concluded that the model fit is good with high reliability and validity. The inter construct correlation was also studied among the six dimensions of impression management, and it was related to the behavioural outcome factors (i.e.) global assignment, work-life balance, and career growth possibilities of employees which is carefully decided by the employees (Belsechak et al., 2010).

Impression management factors influence the $R^{2}$ value of the dependent factor behavioural outcome by $51.2 \%$ in which the impression management strategies influence job growth by $16.4 \%$, work-life balance by $10.6 \%$, regarding global assignment by $49.3 \%$. The results of the study indicate that employees can create impressions towards their superiors in getting global jobs has been top-ranked followed by career growth. There is a vast difference between the two factors because job-related strategies are not determined only by impres- 
sion management factors. However, factors like onsite projects/global assignments, learning, benefits related to work-life balance in the organization (Vijayabanu et al. 2015), might be influenced by impression management strategies of employees.

The impression Management affected primarily human behaviour (Provis, 2010) and the behaviour alterations are made by individuals to avoid negativity (Jain, 2012). The study confirms the path coefficient that model behaviour developed by the individual is $58 \%$. The studies also prove that most people are creating first-rate and first-class impressions since they consider that these impressions created will have long-lasting consequence. Hence, during social interactions within the organization and outside organization individuals develop, control and alter their impressions (Schlenker, 1980). This aspect is also proved in the current study by the influence self-promotion strategies have on the behaviour of individuals (18.1\%). Individuals use impression management strategies and personal branding behaviour on various occasions as a defensive mechanism in the current study by $7.1 \%$ and gain many recompenses in numerous situations (Sharp \& Getz, 1996; Wayne \& Liden, 1995).

The current study is limited to samples which are working only in the IT sector. It has a limitation of the location where the study is confined to one state only. The study can be extended to states and sectors in India. This study can also include samples from different job profiles like sales personnel, agents, sports, media people and healthcare employees.

\section{Conclusion}

Impression Management is an emerging study, and notably it has not been studied to a greater extent in the IT sector. Impression management can be a part of empirical research, and they can also rely more on interviews and qualitative methods. An assessment of diverse impression management strategies in the various field can be studied in areas like sports, psychology, health care, education, hospitality, etc. In 
conclusion, it is believed that the model developed in the current study has endowed with the basis for a broad perspective for the impression-relevant behaviour in the IT sector. Furthermore, it deals with many of the contentious issues in the area of impression management, and it endows with a structure for prospect research. Latest research are exploring the effects of impression management on organizational behaviour and demonstrated how the impression towards others could enhance the self-image of the individual. The current study will be useful to HR policy makers, recruiters, appraisers, and team heads while making decisions to understand the influence of IM techniques followed by the employees to have the desired outcome in the organization.

\section{References}

Avery, D. R. \& McKay, P. F. (2006). Target practice: An organizational impression management approach to attracting minority and female job applicants. Personnel Psychology, 59, 157-187. https:// doi.org/10.1111/j.1744-6570.2006.00807.x

Becker, T. E. \& Martin, S. L. (1995). Trying to look bad at work: Methods and motives for managing poor impressions in organizations. Academy of Management Journal, 38, 174-199. https://doi.org/10.2307/256732

Belschak, F. D., Den Hartog, D. N. \& Fay, D. (2010). Exploring positive, negative and context-dependent aspects of proactive behaviours at work. Journal of Occupational and Organizational Psychology, 83(2), 267-273. https://doi. org/10.1348/096317910X501143

Bingsheng, L., Tengfei, H., Pin-chao, L., Jingfeng, Y., Jiong, S. \& Xuan, H. (2017). A special Partial Least Squares (PLS) path decision modeling for bid evaluation of large construction projects. KSCE Journal of Civil Engineering, 21(3), 579-592. https://doi. org/10.1007/s12205-016-0702-3 
Bolino, M. C. \& Turnley, W. H. (1999). Measuring impression management in organizations: A scale development based on the Jones and Pittman taxonomy. Organizational Research Methods, 187-206. https://doi.org/10.1177/109442819922005

Bolino, M., Long, D. \& Turnley, W. (2016). Impression management in organizations: Critical questions, answers, and areas for future research. Annual Review of Organizational Psychology and Organizational Behaviour, 3, 377-406. https://doi.org/10.1146/ annurev-orgpsych-041015-062337

Bourdage, J. S., Wiltshire, J. \& Lee, K. (2015). Personality and workplace impression management: Correlates and implications. Journal of Applied Psychology, 100(2), 537-546. https://doi.org/10.1037/ a0037942

Brouer, R. L., Gallagher, V. C. \& Badawy, R. L. (2016). Ability to Manage Resources in the Impression Management Process: The Mediating Effects of Resources on Job Performance. Journal of Business and Psychology, 31(4), 515-531. https://doi.org/ 10.1007/s10869-015-9426-5

Chin, W. W. (1998). Issues and opinion on structural equation modeling. MIS Quarterly, 22(1), 7-16.

Drory, A. \& Zaidman, N. (2007). Impression management behaviour: effects of the organizational system. Journal of Managerial Psychology, 22, 290-308. https://doi.org/10.1108/ 02683940710733106

DuBrin, A. J. (2011). Impression management in the workplace: Research, theory, and practice. New York, NY: Routledge. https://doi. org/10.4324/9780203865712

Feldman, D. C. \& Klich, N. R. (1991). Impression management and career strategies. In R. Giacalone y P. Rosenfeld (Eds.), Applied impression management: How image-making affects organizations (pp. 67-80). Newbury Park: Sage Publications.

Fornell, C. \& Larcker, D.F . (1981). Evaluating structural equation models with unobservable variables and measurement error. 
Journal of Marketing Research, 18(1), 39-50. https://doi.org/ $10.2307 / 3151312$

Gaes, G. G., Kalle, R. J. \& Tedeschi, J. T. (1978). Impression management in the forced compliance situation: Two studies using the bogus pipeline. Journal of Experimental Social Psychology, 14, 493-510. https://doi.org/10.1016/0022-1031(78)90045-8

Gardner, W. L. \& Martinko, M. J. (1988). Impression management in organizations. Journal of Management, 14, 321-338. https://doi. org/10.1177/014920638801400210

Giacalone, R. A. \& Rosenfeld, P. (2013). Impression management in the organization. New York: Psychology Press. https://doi.org/ $10.4324 / 9780203763018$

Goffman, E. (1959). The Presentation of Self in Everyday Life. Garden City, NY: Doubleday.

Gove, W. R., Hughes, M. \& Geerken, M. R. (1980). Playing dumb: A form of impression management with undesirable side effects. Social Psychology Quarterly, 43, 89-102. https://doi.org/ $10.2307 / 3033751$

Jain, A. K. (2012). Moderating effect of impression management on the relationship of emotional intelligence and organizational citizenship behaviour. Journal of Behavioral and Applied Management, 13(2), 86-107.

Jones, E. E. \& Wortman, C. (1972). Ingratiation: An attributional approach. Morristown: General Learning Press.

Kacmar, K. M., Harris, K. J. \& Nagy, B. G. (2007). Further Validation of the Bolino and Turnley Impression Management Scale. Journal of Behavioral and Applied Management, 9(1), 16-32.

Kacmar, K. M. \& Tucker, R. (2016). The moderating effect of supervisor's behavioural integrity on the relationship between regulatory focus and impression management. Journal of Business Ethics, 135(1), 87-98. https://doi.org/10.1007/ s10551-014-2464-5

Kenneth, J. H., Michele, K. K., Suzanne, Z. \& Jason, D. S. (2007). The impact of political skill on impression management 
effectiveness. Journal of Applied Psychology, 92(1), 278-285. https://doi.org/10.1037/0021-9010.92.1.278

Leary, M. R. \& Kowalski, R. M. (1990). Impression management: A literaturereviewand two-componentmodel.PsychologicalBulletin, 107, 34-47. https://doi.org/10.1037/0033-2909.107.1.34

Mark, C., Bolino, A., Klotz, C. \& Daniels, D. (2014). The impact of impression management over time, Journal of Managerial Psychology, 29(3), 266-284. https://doi.org/10.1108/JMP-102012-0290

McFarland, L. A., Ryan, A.M. \& Kriska, S. D. (2003). Impression management use and effectiveness of assessment methods. Journal of Management, 29, 641-661. https://doi.org/10.1016/ S0149-2063(03)00030-8

Mohamed, A. A., Gardner, W. L. \& Paolillo, J. G. (1999). A taxonomy of organizational impression management tactics. Advances in Competitiveness Research, 7(1), 108-130.

Montagliani, A. \& Giacalone, R. A. (1998). Impression management and cross-cultural adaption. The Journal of Social Psychology, 138(5), 598-608. https://doi.org/10.1080/00224549809600415

Peck, J. A. \& Hogue, M. (2018). Acting with the best of intentions... or not: A typology and model of impression management in leadership. The Leadership Quarterly, 29(1), 123-134. https:// doi.org/10.1016/j.leaqua.2017.10.001

Porter, C., Hollenbeck, J. R., Ilgen, D. R., Ellis, A. P., West, B. J. \& Moon, H. (2003). Backing up behaviours in teams: The role of personality and legitimacy of need. Journal of Applied Psychology, 88, 391-403. https://doi.org/10.1037/0021-9010.88.3.391

Provis, C. (2010). The ethics of impression management. Business Ethics: A European Review, 19(2), 192-212. https://doi. org/10.1111/j.1467-8608.2010.01584.x

Rosenfeld, P. R., Giacalone, R. A. \& Riordan, C. A. (1995). Impression management in organizations: Theory, measurement, and practice. New York: Routledge. 
Rosenfeld, P., Edwards, J. E. \& Thomas, M. D. (2015). Impression management. Wiley Encyclopedia of Management, 1-2. https:// doi.org/10.1002/9781118785317.weom110164

Schlenker, B.(1980). Impression Management: self-concept, social identity, and interpersonal relations. Belmont: Wadworth, Inc.

Sharp, M., Getz, J. \& Greg, J. (1998). Self-process in comorbid mental illness and drug abuse. American Journal of Orthopsychiatry, 68(4), 639-644. https://doi.org/10.1037/h0080372

Soran, S. \& Balkan, M. O. (2013). The effects of impression management tactics on emotional expressions: Research on the banking sector. Journal of Global Strategic Management, 7(1),154-165. https://doi.org/10.20460/JGSM.2013715681

Spence, J. R. \& Keeping, L. (2011). Conscious rating distortion in performance appraisal: A review, commentary, and proposed framework for research. Human Resource Management Review, 21(2), 85-95. https://doi.org/10.1016/j.hrmr.2010.09.013

Therasa, C. \& Vijayabanu, C. (2016). A dispositional approach to examine the impact of students stressors in the Indian context. Journal of Educational, Cultural and Psychological Studies, 14, 35-56. https://doi.org/10.7358/ecps-2016-014-ther

Therasa, C. \& Vijayabanu, C. (2016). Person-job fit and the work commitment of IT Personnel. Journal of Human Growth and Development, 26(2), 218-227. https://doi.org/10.7322/jhgd. 119277

Vijayabanu, C. \& Therasa, C. (2016). The Leveraging Effect of Supervisory Competencies Towards the Performance in Indian Manufacturing Group: A Structural Equation Modelling Approach. Journal of Organizational Transformation and Social Change, 13(3), 220-234. https://doi.org/10.1080/14779633.2 016.1237147

Vijayabanu, C., Renganathan, R. \& Govindarajan, K. (2015). The upshot of the learning organization: a Case study of an Indian private-sector bank using the PLS-SEM model. Journal of 
Organisational Transformation and Social Change, 12(2), 178192. https://doi.org/10.1179/1477963315Z.00000000041

Wayne, S. J. \& Kacmar, K. M. (1991). The effects of impression management on the performance-appraisal process. Organizational Behaviour and Human Decision Processes, 48, 70-88. https://doi.org/10.1016/0749-5978(91)90006-F

Wayne, S. J. \& Liden, R. C. (1995). Effects of impression management on performance ratings: A longitudinal study. Academy of Management Journal, 38(1), 232-260. https://doi. org/10.2307/256734

Wayne, S. J. \& Liden, R. C. (2011). Effects of Impression Management in the Workplace: Research, Theory, and Practice. New York: Taylor $\&$ Francis.

Zerbe W. J., Paulhus D. L. (1987). Socially desirable responding in organizational behaviour: a reconception. Acad. Manag. Rev., 12(2), 250-264. https://doi.org/10.5465/amr.1987.4307820

Zivnuska, S., Kacmar, K. M., Witt, L. A., Carlson, D. S. \& Bratton, V. K. (2004). Interactive Effects of Impression Management and Organizational Politics on Job Performance. Journal of Organizational Behaviour, 25(5), 627-640. https://doi.org/ 10.1002/job.262

Recibido: 09 septiembre 2018

Revisado: 15 diciembre 2018 Aceptado:10 mayo 2019 